Hamiduddin, I; (2015) Social sustainability, residential design and demographic balance: Neighbourhood planning strategies in Freiburg, Germany. Town Planning Review , 86 (1) pp. 29-52. 10.3828/tpr.2015.3. Downloaded from UCL Discovery: http://discovery.ucl.ac.uk/1461694

\title{
ARTICLE
}

\section{Social sustainability, residential design and demographic balance: neighbourhood planning strategies in Freiburg, Germany}

\author{
Iqbal Hamiduddin, Faculty of the Built Environment, UCL (University College London)
}

\begin{abstract}
Social sustainability remains a relatively underdeveloped and contested field. Recalling older notions of social mixing and 'balanced neighbourhoods' two concepts of 'sustainability of community' and 'social equity' have recently emerged as core social sustainability principles, but uncertainty remains over the spatial scale at which the principles should be applied. The aim of this paper is to broaden the existing literature by means of detailed case study research on neighbourhood development in the German city of Freiburg, where demographic concentration has led to ageing in place and the undermining of community infrastructure and services. Although new car-reduced neighbourhoods of Vauban and Rieselfeld look likely to replicate this pattern, the city has shifted policy towards smaller 'fresh cell' developments designed to inject younger residents into ageing neighbourhoods to create a more even social balance, viable services and community infrastructure.
\end{abstract}

\section{Introduction}

Although sustainability discourses continue to dominate governance and planning policy agenda across Europe (Rydin, 2010), the social dimension often remains eclipsed by environmental and, by economic concerns. If, as a number of authors propose, these three elements together form a sustainability 'triple-bottom-line' (Davidson, 2010: 872) or even a 'three legged stool' (Evans, 2009:686) then, for many, a disjointed and uneven work remains. Reasons for this continuing anomaly are varied. Vallance et al, 2011:343) note that the term social sustainability has become intimately associated with a 'brown-agenda' concerned with social development in less developed and developing countries, with only limited relevance to the higher-order needs of concern to policy makers in more developed societies. Another reason is simply that the 'conceptual chaos' undermining the utility of the term (Vallance et al, 2011: 342) means that, in the absence of an agreed definition, common principles or goal, this element of sustainability may best be put aside until greater conceptual clarity prevails.

Ultimately therefore social sustainability remains widely viewed as a work in progress. Recently, however, the two concepts of 'sustainability of community' and 'social equity' (Dempsey et al, 2012; Bramley et al, 2006) have begun to anchor the term more securely, and have emerged to tether a range of supporting factors including social inclusion, social capital, safety and residential stability (Dempsey et al, 2011: 291). In this way, the emergence of the two concepts as a structuring framework for a range of related and 
interdependent concepts has reinforced social sustainability's relevance for all societies, and has begun to draw on deeper, historic interests about residential social mix (Sarkissian, 1976) and 'social balance' (Mann, 1958) across urbanised societies.

Directly recalling these older ideas of social mix and neighbourhood balance, sustainability of community has been defined as the "ability of society itself, or its manifestation as local community, to sustain and reproduce itself at an acceptable level of functioning" (Dempsey et al, 2012: 94), while social equity is rooted in ideas of social justice, distributive justice and equality (Dempsey et al, 2011: 292). The scope and complexity of the ideas that the two concepts draw upon mean that unresolved tensions can surface, for example between the cohesive and exclusionary forces of social capital (Putnam, 2000) in community planning, the contested notions and evaluation of 'community' itself (e.g. Harvey, 2000), and in the detail of community-strengthening factors including the stability of a residential population (Sarkissian, 1976: 233) against the long term regenerative force of residential turnover. Putting these detailed arguments to one side, a significant, if basic and long running conceptual difficulty arises over the question of spatial scale, and the physical units of planning to which the principles of social sustainability should apply. As Sarkissian (1976:243) notes 'throughout decades of discussion on social mix, remarkably little attention has been paid to the vital question of scale. What is the unit which the mixers propose to mix?' The author notes how the scale of mix has shrunk 'more by accident than by design', through Edward Gibbon Wakefield's mixed colony in New Zealand, through the scales of garden city and suburb by Ebenezer Howard and finally to the finer detail of Clarence Perry's Neighbourhood Unit (Sarkissian, 1976:243). The question of physical scale and the extent to which local communities should relate to and reflect society appears unresolved against the scalar gap between 'society' and the non-specific but pervasive level of 'local community'.

On the specific demographic aspect of age structure as a social sustainability concern, the existing literature is relatively quiet. The overall aim of this paper, therefore, is to broaden this particular aspect of the social sustainability agenda by exploring how the age structure of neighbourhoods can be important to its long term prospects, and particularly in relation to attendant factors of spatial extent in creating large scale cohorts and housing delivery and market dynamics in producing the conditions for large-scale ageing in place. Using the two concepts of social sustainability set out by Dempsey et al (2012) and by way of a case study of Freiburg, this paper has two operational objectives; firstly, to demonstrate the relationship between neighbourhood design and demographic composition of residential community, and secondly to demonstrate the implications of demographic concentration on both sustainability of community and social equity.

To these two ends, the remainder of the paper is organised in three main parts. The first part begins by reviewing the term social sustainability before focussing on recent residential car reduction strategies integral to creating environmental and social 'exemplar' neighbourhoods and the effects on the demographic composition of these neighbourhoods through processes of self-selectivity identified in the literature. The findings from the first part are carried forward to the second which compares the physical qualities, demographic characteristics and community development indicators of the two renowned, car-reduced neighbourhoods of Vauban and Rieselfeld in the Southern German city of Freiburg, with a third reference neighbourhood of the same city. Freiburg's burgeoning younger population, the family-friendly car-reduced neighbourhood design used at Vauban and Rieselfeld, and the family-oriented group self-build approach to housing delivery used in the two 
neighbourhoods are identified as key factors in accounting for the concentration of young families there. The phenomenon in the two modern neighbourhoods replicates a wider pattern of demographic concentration in Freiburg's older inter-war and post-war neighbourhoods, where cohorts of younger residents originally settled into the newly completed housing estates en mass and have remained ever since. Ageing and subsequent depopulation both undermines the viability of amenities including public transport services, local shops and schools (Siedentop \& Fina, 2010) and skews demand towards other services including healthcare. In this way, it is argued, Freiburg's 'cohort effect' challenges the two key principles of social sustainability, in the first instance by undermining 'sustainability of community' by creating neighbourhood communities that are unrepresentative of the city's wider community and which can only self-regenerate after prolonged decline through ageing, which has created a secondary effect of imperilling the equitable access of residents to the full spectrum of opportunities. In response to this cohort effect, the third and final part introduces the recently introduced residential design response of Freiburg's planners to create 'fresh cell' schemes (Daseking, 2010) - small car-reduced and group self-build developments - used to 'inject' younger residents into ageing neighbourhoods.

\section{Social Sustainability and Neighbourhoods}

Even by the standards of a relatively underdeveloped field (Dempsey et al, 2009), comparatively little attention has been directed towards the term social sustainability at the neighbourhood scale, although a more extensive body of work exits on related factors such as social interaction, capital and equity at this geographical scale. As a broad, aspatial, but underdeveloped idea, social sustainability is viewed by some as a 'master signifier' (Hillier, 2007:197) or the 'kernel' of an idea (Žižek, 1989:80) serving to 'anchor complex and diverse arguments' (Hillier, 2007:197); an idea which is perhaps understood implicitly but which currently lacks specificity. Dempsey et al (2011 and 2012) have recently sought to 'populate' the concept as a discrete and self-serving entity by constructing a framework from foundations laid down by Stren and Polèse (2000: 16-17), who define social sustainability as: development (and/or growth) that is compatible with the harmonious evolution of civil society, fostering an environment conducive to the compatible cohabitation of culturally and socially diverse groups while at the same time encouraging social integration, with improvements in the quality of life for all segments of the population

Building on this broad definition, a framework based on two principal concepts of social equity and sustainability of community by Bramley et al (2009) was developed for the purpose of investigating different elements of urban form on different aspects of social sustainability (Dempsey et al, 2012). Social equity is a concept rooted in social justice notions of fairness in the distribution of resources, avoidance of exclusion, and full participation of residents in all aspects of society (Dempsey et al, 2012:94) and, in operational terms, can relate to both the geographical distribution of amenities, opportunities and employment and also the provision of the means to access them, such as transportation or other forms of communication. The geographical or horizontal dimension of equity is important (Kay, 2005), with spatial imbalances manifested by deprivation with reduced access to facilities and a poorer living environment (Dempsey et al, 2009: 292).

The second concept - sustainability of community - is defined as 'the ability of society itself, or its manifestation as local community, to sustain and reproduce itself at an acceptable level of functioning' (Dempsey et al, 2009: 293). The sustainability of a community is strongly 
associated with notions of 'social capital' and 'social cohesion', which are the product of trust and social relations developed through interaction between residents, participation in community institutions, relative stability of community, and positive identification with a place (Dempsey et al, 2011; Bramley and Power, 2008; Forrest and Kearns, 2001). More specifically, Bramley et al (2006:5) identify five key measurable aspects of social life which can be used as indicators of community sustainability: (i) social interaction and networks, (ii) participation in community groups and networks, (iii) community stability, (iv) pride or sense of place, and (v) safety and security.

\subsection{Residential Demographics}

Residential demographic composition by age profile has received significantly less attention and has been somewhat overlooked as a factor in comparison with other indicators of social mix including employment patterns (Polèse and Stren, 2010). Although age is not always a significant factor in its own right, specific aspects can directly influence mechanisms which contribute to sustainability of community, including the presence (or absence) of children in catalysing wider community relations at the local scale (Portes, 2000) or, the impact on labour market supply at the city and regional scales (Raco, 2007). In northern European countries population ageing has become a significant policy concern, and in an areas of northern and eastern Germany ageing is particularly widespread (Muller and Siedentop, 2004). Here there are concerns about long term population regeneration, the ability of cities to maintain balanced and competitive labour forces and maintain sufficient tax revenues to support public services.

However, similar concerns can apply at the urban district scale, even in cities where healthy age profiles exist overall and in Freiburg the problems associated with district scale ageing and depopulation are discussed later in this paper. Here, district scale ageing caused by the simultaneous settling of young family cohorts in new-build suburbs during the 1970s has been compounded by very low levels of household turnover or market 'churn'. In social sustainability terms, the situation presents paradoxical 'mobility-fixity tensions' (Raco, 2007:8) between population stability (as an agent for social relations) on the one hand, and turnover as a means to maintaining demand for local community infrastructure on the other. This temporal element also has a strong spatial crossover, relating partly to political questions of how broader society should be represented at different spatial scales and, more prosaically, to scales of community infrastructure provision, the accessibility of services and amenities for different sectors of a population and, returning to the temporal theme once again, how the economic viability of such services can be maintained in the long term (Siedentop \& Fina, 2010). A dearth of existing literature on this does not mean the absence of a problem, particularly in the under-developed field of social sustainability. Moreover, because different issues come to the fore in different localities and at different spatial scales, localised problems can be overlooked, particularly where sufficiently high resolution data has not been collected or analysed. The nature of the issues of age profile explored in this paper might be viewed as locally specific and culturally influenced, but they also illustrate these broader issues of under-reporting of the finer detail, at a scale particularly salience to planning at the neighbourhood scale.

\subsection{Social Equity and Neighbourhood Qualities}


Social equity includes the ability for residents to access services and opportunities (Bramley et al, 2009:2126) and physical planning at the neighbourhood scale can play a potential important role in creating opportunities for access by shortening travel distances between homes and local amenities, and by providing the transportation options to access further opportunities. Local amenities can exert important influences on individual well-being and social cohesion in turn by meeting daily functional needs and creating opportunities for incidental encounters and the development of social relations. Indeed the layout, institutions and communal spaces of the Neighbourhood Unit were set out by Clarence Perry $(1939: 251)$ in the belief that:

when residents are brought together through the use of common recreational facilities they come to know one another better and friendly relations ensue. Existing developments with neighbourhood unit features have consistently produced face-toface conditions.

However as Mann (1958:91) notes, the effects of direct contact shouldn't be overstated as 'face-to-face social conditions is not necessarily the same thing as to produce friendship', although it remains an important precondition. More recently, urban compaction has been viewed as a planning policy instrument for reducing travel distances and improving accessibility to amenities from the home. Dempsey et al (2012) investigated a number of confident but largely unsubstantiated claims made by policy makers about the benefits of higher urban densities in reducing travel distances, private car travel, and therefore exclusion from services and facilities. Although density had a generally positive effect on the use of local services, produced an overall reduction in car travel, and had merit in social equity terms, the authors also found that increasing density had negative implications including a reduction in green space and lower use of communal parks and gardens which could potentially undermine personal well-being. Recently environmental psychologists have begun to correlate access to natural spaces with improved mental health (Maller et al, 2005; Kaplan, 1995), reduced levels of aggression and crime (Kuo \& Sullivan, 2001) and, in some instances, greater social interaction among different age groups (Strife \& Downey, 2009). These studies indicate that the potential benefits of density of the built environment and the disadvantages of the potential loss of green space need to be weighed carefully.

Green spaces have also served as a means to reducing the impact of the car in the residential environment. At both Unwin and Parker's Hampstead Garden Suburb plan and Stein's design of Radburn, road carriageway space has been substituted by gardens and landscaped setbacks to create buffers between traffic and residents (Southworth and BenJoseph, 2002; Barnett, 1986; Hass-Klau, 1990). In the design of his Neighbourhood Unit concept, Perry also identified the detrimental effect of traffic on the social qualities of the neighbourhood that were formally documented by Appleyard and Lintell (1971) nearly five decades later. Increases in road traffic through residential areas demonstrably diminish social relations among residents (Appleyard et al, 1981; Hart \& Parkhurst, 2011) as a direct consequence of a less socially conducive environment, by the disruptive effect of continuous traffic flows (Hillman et al, 1990), or by secondary effects including the 'coping mechanisms' deployed by residents ranging from the drawing of curtains, to a retreat to the rear of a home (Appleyard et al, 1981). Although the negative effects of road traffic in the urban environment causes a number social equity issues, including the specific social justice implications over the location of new transportation routes, the treatment of traffic in the neighbourhood requires a sensitive balancing act between the needs of residents as both potential car users 
and home dwellers. For this reason, Perry proposed an internal street layout within his Neighbourhood Unit that discouraged through-traffic, and this formed the basis for Clarence Stein's plans for Radburn, New Jersey, designed to for residents to 'live peacefully with the automobile-or rather in spite of it' (Stein, 1950), and this later informed Colin Buchanan's residential 'environmental areas' in the UK (Hass-Klau, 1990).

\subsection{Neighbourhood car reduction and demographic balance}

The qualities of different residential areas may lead to processes of self-selectivity in turn, such as in relation to social factors including ethnicity and the desire to live in proximity to a particular type of community or group (Smith \& Furuseth, 2004) or physical factors including the particular built qualities of a neighbourhood (Handy et al, 2006). Residential selfselection may influence travel behaviour in turn, where residents holding particular attitudes, values and demographic traits are drawn to particular environments that are oriented towards particular travel modes - for example a high quality urban realm for walking or particular public transport modes (Mokhtarian \& Cao, 2008). In this way, travel preferences can be considered as a dominant aspect of wider lifestyle choice with residential selfselection as the outcome. The role of self-selectivity on determining overall travel behaviour remains unclear in relation to the shaping influence of neighbourhood characteristics. To illustrate this research shortfall, Handy et als (2006) study on the role of self-selection in the relationship between the built environment and walking found that although selectivity had an influence, accessibility to shops and services was probably more important, and that other physical and social qualities of the eight neighbourhoods examined also had an important influence. The study indicated that the physical environment could play a deterministic role, yet because different features and qualities occur together it was difficult to untangle direct causes and effects.

\section{[Table One about here]}

Continuing the earlier work of Perry, Stein, Buchanan and others, residential models have evolved with the proliferation of the car during the twentieth century, and as a result of increasing awareness of traffic's social impact and, with it, the development of mitigating measures (Appleyard et al, 1981; Hass-Klau, 1990). These measures have broadly taken the form of physical or regulatory measures to limit the impact of cars in the residential setting such as by altering driving behaviour or separating vehicles from homes, encouraging residents towards using alternative transport modes including bygiving spatial priority to alternatives or, perhaps most stridently, by placing regulatory or physical limits on car ownership. Examples of the physical and regulatory measures to limit car ownership, use and impact are set out in Table One, while Table Two shows how the measures have been deployed in a range of residential schemes.

\section{[Table Two about here]}

Studies have attempted to characterise the residential populations of the schemes as shown in Table Two. Table Three describes the overall car intervention 'package' used in each scheme before summarising the findings of studies using indicators to capture social aspects from each of the schemes including demographic information about the resident community, and lifestyle patterns - including modal share and travel patterns. Two demographic and two mobility indicators that have been used across the include household size, the proportion of 
highly educated residents employed in white collar jobs, household car ownership, and car use for the journey to work or major daily journey.

\section{[Table three about here]}

Table Three strongly indicates the appeal of car reduced development to families with young children, and to highly educated professional workers a significant proportion of whom are likely to be sympathetic to the social and environmental objectives of this development approach (Nobis \& Welsch, 2003; Scheurer, 2001). In mobility terms, the evidence suggests that car-reduced schemes have been successful in reducing both car ownership and car use compared with local prevailing norms. However, a degree of caution needs to be applied to Slateford Green, where approximately two thirds of homes are for shared ownership or rent with a housing association (Scheurer, 2001), and at BedZed where a half of homes are under shared ownership or social rent (Chance, 2009). Similarly, about thirty percent of Rieselfeld's homes are for social housing (Ryan and Throgmorton, 2003). Slateford Green, BedZed and Rieselfeld have high proportions of residents who are less likely to be car owners; a point confirmed by a study at Slateford Green by Eastwood (2008) which found that just under a half of residents held a driving licence. Nevertheless, these demographic traits indicate a degree of residential self-selectivity.

\subsection{Three neighbourhoods compared}

Three Freiburg neighbourhoods are compared in the following sections, consisting of a 1700 home 'car-free' scheme at Vauban, where robust measures have been implemented to reduce car ownership, use and impact, a 3500 home 'low car' scheme at Rieselfeld where measures have been directed to reducing car use and impact, and the 3800 home Haslach Gartenstadt district as a reference or 'regular' neighbourhood typical of Freiburg. The three neighbourhoods are located on the outer fringes of Freiburg, with Haslach Gartenstadt the most central at $2 \mathrm{~km}$ from the city centre, Vauban at approximately $3.5 \mathrm{~km}$ and Rieselfeld the most distant at $4.5 \mathrm{~km}$. Each has a similar level of service provision (Table Five), including tram service to the city centre and radial bus services to other parts of the city and beyond, retail stores including supermarkets, schools and medical facilities. However, two significant differences between Haslach Gartenstadt and the new developments include the lack of cycle storage facilities and dedicated car parking in the former.

\section{[Table four about here]}

The following sections compare the demographic composition, indicated travel patterns and social relations in the three neighbourhoods. Three different data sets were used: (i) secondary demographic data from household returns compiled by the City of Freiburg statics bureau (City of Freiburg, 2007 and 2010), (ii) primary household questionnaire survey on travel, social contact and attitudes conducted by the author, and (iii) semi-structured interviews. To provide greater detail a household questionnaire survey was conducted across households across each of the three neighbourhoods ${ }^{1}$. At Vauban the completed survey forms were collected at the Quartiersladen or residents' cooperative shop, where respondents received a $€ 1$ reduction on their shopping. In Rieselfeld, a collection point established at the 'Kiosk' community centre, in the centre of the neighbourhood, and

\footnotetext{
${ }^{1}$ A more extensive description of the survey and detailed examination of the findings are presented in Hamiduddin and Daseking (2014). Survey sample are (n) as follows: Vauban (92), Rieselfeld (95), and Haslach (76)
} 
additional forms were distributed at a twice-weekly market. In Haslach, forms initially recovered by hand from each household, in the absence of a neighbourhood focal point, whilst forms from a second survey distribution were recovered by mail back envelope. An overall response rate of $12 \%$ was lower than expected but not untypical of data collection of this nature. Lastly, a total of twelve semi-structured interviews were conducted with a range of actors involved in the planning and development of Freiburg's new neighbourhood schemes, including planning officers, community officials and residents themselves. ${ }^{2}$

\section{Sustainable Development in Freiburg}

The remainder of the paper explores the linkages between residential design, age structure and social sustainability through a range of indicators from the residential schemes at Vauban and Rieselfeld, schemes recently been described as 'jewels' in Freiburg's 'crown' (Academy of Urbanism, 2011). The empirical research is formed around two research objectives. The first objective, which forms the focus of this section, is to examine the relationship between neighbourhood design and demographic composition of residential community, whilst the second - the focus of section four - is to examine the implications of demographic concentration on sustainability of community and long term social equity. In contrast to other areas of Germany, Freiburg's population has grown from 177,000 in 1989 to over 200,000 in 2009 (City of Freiburg, 2010) due largely to university graduates settling in the city after graduation (Ryan and Throgmorton, 2003). Unlike other cities in Germany, therefore, Freiburg has grown steadily since the middle of the twentieth century. In order to accommodate a sustained expansion of its post-war population and a general orientation of travel towards the private car, the city expanded outwards in the 1960s with the creation of suburbs at Weingarten in the south and Landwasser-Mooswald in the west of the city, built in a modernist style of tall apartment blocks surrounded by green space. The 1970s and 1980s saw the arrival of low density housing developments in the southern suburbs at St Georgen. The city's continued expansion from an inward migration of young students does not make it an obvious case study for investigating the social sustainability implications of ageing neighbourhoods. However, a more detailed, historic study shows that newly completed, these suburbs became home predominantly to young families but have since experienced low levels of population turnover and are now characterised by population decline as the original residents have aged (A; City of Freiburg, 2007). Table five shows the effects of stagnation in the suburb of Mooswald, built in the 1970s. Here ,the wider contemporary relevance for Freiburg's new neighbourhoods is in the cultural underpinnings of the low housing market turnover which has led to these demographic traits. Although the fine details have changed over time, the overall pattern has been to produce housing to meet enduring demand from young families, creating 'cohort neighbourhoods' whose residents remain in place.

\section{[Table five about here]}

\subsection{Freiburg's New Neighbourhoods}

\footnotetext{
${ }^{2}$ Attributions in the following text have been selected from a spread of five interviewees and are cited as follows: (A) The former Director of Planning for the City Freiburg; (B) Transport Planner for the City of Freiburg; (C) Manager of the Vauban Car-Free Association; (D) Architect and Baugruppe leader in Rieselfeld and Vauban; and (E) Baugruppe resident of Vauban.
} 
Of Freiburg's two large new neighbourhood districts, Rieselfeld is the product of the city's long term planning policies to provide new housing, while Vauban may described as the outcome of an unexpected 'windfall' site. After the end of the Cold War in 1991, the departure of the French army garrison from the Vauban barracks within the southern city boundary provided a large site for redevelopment, whilst protestors who claimed some of the disused buildings lobbied for an ecologically-oriented scheme and established a formal body which entered into negotiation with the city administration. The schemes have been shaped through the participation of the local community permitted through Southern Germany's devolved structure of political power and strong tier of local planning, enacted within regional and national constraints, by municipal government led by a directly elected city Mayor (Hamiduddin and Daseking, 2014). The influence of communities on local planning has produced two innovative approaches (ibid). The first is a participatory approach in which local community contributed to the shaping of the Vauban neighbourhood masterplan, while the second is the use of a collaborative group-build approach to housing development at both Vauban and Rieselfeld (Hamiduddin \& Gallent, 2013). Rather than selling an entire site to a single developer, the municipal authority made public land available for collaborative self-build development by Baugruppen - literally 'building groups' - at Vauban and at the larger Rieselfeld site. The approach has enabled groups of prospective householders to collaborate finances and creative energy in the production of customised buildings containing homes tailored to suit the requirements of each household. A group may be initiated by a construction professional, typically an architect experienced in project management - but may also simply be a prospective resident, while the other members of the group are responsible for raising the finance for their home on an individual basis (Hamiduddin and Gallent, 2013). Residents also contribute to the design and sometimes to the physical realisation of their building. This approach therefore offers two potentially attractive aspects: firstly, a high level of input into the design and construction process, and secondly potentially significant cost savings over conventional developer-led housing (Barlow et al, 2001:18).

As shown previously in table three, Vauban and Rieselfeld share similarities in physical qualities; morphologically, both are oriented towards a central tram-served axis, have extensive car free areas formed by green areas and 'superblock' patterns, are designed with travel reduction and physical mobility in mind, and both employed a Baugruppe or communal build approach to residential development. However, Vauban has made more strenuous efforts to reduce car ownership through the creation of stellplatzfrei or car-parking free housing. Residents wishing to own a car must purchase a place on an edge of development garage at a cost of $€ 18,000$ (at the time of writing). Rieselfeld has no similar stringent measures to limit ownership, but here planners have focussed on reducing car use and impact. The third neighbourhood of Haslach Gartenstadt has no specific car reduction features, though in keeping with general Freiburg policy, many streets are designated as $20 \mathrm{~km} / \mathrm{h}$ 'home zones' where pedestrian activities have priority over the car, and some streets have 'shared surfaces' where pedestrians and traffic mix. A similar combination of home zones and shared surfaces has been used in Rieselfeld, although main traffic thoroughfares have incorporated landscaping into cross-sectional design to ameliorate the worst impacts of traffic. In Vauban almost all streets are shared surface and vehicle access is limited to setting-down and collection only with minimal parking near the home.

\subsection{Car reduction: policy outcomes}


Across the city, Freiburg's municipal authority has implemented a mixture of 'carrot and stick' measures to orientate residents away from private car use by simultaneously improving and prioritising non car travel networks and services, and implementing restrictive measures to car travel, for example by reducing parking and reorienting street space away from traffic (A $\& B)$. An overall stagnation in car use has recently been observed with the proportion of cars and light trucks per 1000 inhabitants remaining at around 420 since 2006, compared with an average of 546 for Germany (Buehler \& Pucher, 2011; Hamiduddin, 2014). At Rieselfeld the ratio is 290 cars per 1000 inhabitants, whilst the Vauban ratio is 170 , however this measurement is crude as it does not take account of the differences in demographic structure and household size. Accounting for demographic factors, therefore, Table Six shows that Vauban's household car ownership rate is $48 \%$ - substantial for a neighbourhood that has employed strident car reduction measures - but a third less than the Freiburg average of $74 \%$. Rieselfeld has a relatively high household ownership rate of $72 \%$, reflecting a more 'relaxed' posture towards private vehicle ownership, while Haslach's relatively central inner city location may contribute to a below average ownership rate of $64 \%$. The relevance of these measures to neighbourly relations is discussed below.

\section{[Table Six about here]}

\subsection{Neighbourly Relations}

Social contact between residents of the three neighbourhoods, as shown below in table seven, varies significantly. A more extensive investigation of community development is provided in Hamiduddin and Daseking (2014) and a greater range of indicators are provided which reinforce the pattern shown below in table seven. Although exact causation has not been established, a number of explanatory factors are proposed. Chief among which is the varying use of group self-build as a mode of housing delivery model in each of the neighbourhoods, accounting for $25 \%, 10 \%$ and $0 \%$ of the overall housing stock at Vauban, Rieselfeld and Haslach, respectively. The questionnaire survey was distributed to a sample of homes across each neighbourhood ${ }^{3}$, and asked residents to specify how many people they knew by name on their street. Although the range of results was considerable, varying from zero in the case of residents who had recently arrived to 150 for one long time resident in Haslach, Vauban residents knew an average of three times as many of their neighbours as residents of Haslach, with Rieselfeld residents approximately halfway between the two. The substantial differences in household size may exert an influence here. If 'persons known' are converted into 'households known' using the household occupancy data for each of the developments, the differences narrow somewhat to an average 32 households for Vauban residents, 25 households at Rieselfeld, and 11.5 for Haslach residents, although the overall pattern of stronger neighbourly relations in the newer developments remains. Another section of the survey also asked residents how often they greet a neighbour and the findings, reported comprehensively in Hamiduddin and Daseking (2014) depicted a similar pattern, with $73 \%$ of Vauban residents reportedly greeting a neighbour on a daily basis, compared with $48 \%$ in Rieselfeld and $36 \%$ among Haslach residents.

\footnotetext{
${ }^{3}$ The survey included samples from the mix of housing stock in each neighbourhood, but tenure was not known.
} 


\section{[Table seven about here]}

\section{Population structure and ageing}

Vauban and Rieselfeld households are larger, have more children, but are much less likely to have members of the upper age bracket compared with the reference neighbourhood of Haslach and the overall Freiburg average. Indeed, population age differences between the neighbourhoods are significantly more pronounced at the upper and lower margins. Whilst residents in the $25-35$ and $35-60$ brackets are broadly similar, $20.6 \%$ and $21.3 \%$ of Vauban and Rieselfeld residents respectively belong to the 6-18 age group - double the $10.8 \%$ proportion at Haslach and $10.5 \%$ overall Freiburg average. Conversely, the over 65 age group represents just $2.1 \%$ of Vauban and $5.7 \%$ of Rieselfeld residents, very significantly below the $16.5 \%$ of over 65 year olds at Haslach and $16.9 \%$ overall average for Freiburg. Household sizes - which stand at 2.95 inhabitants per household at Vauban and 2.56 at Rieselfeld are much larger than both the 1.89 average at Haslach and the overall Freiburg average of 1.92. The differences in household occupancy, reflecting both the proportion of children and the proportion of older age residents in each neighbourhood, are pronounced, indicating a process of residential self-selectivity at Vauban and Rieselfeld.

\section{[Figure one about here]}

\subsection{Residential self-selectivity}

Although a detailed analysis of self-selectivity causal processes has not been undertaken, interviews with policy managers and residents indicate that four factors in particular have affected residential profile: (i) the city's continuing housing demand from a burgeoning younger demographic of university leavers, (ii) Vauban's unique historic background as a physical legacy of environmental protest since the 1960s, (iii) the group build model used to deliver 480 homes or approximately one quarter of homes at Vauban and around 400 or $10 \%$ of homes at Rieselfeld, and (iv) the residential design of Vauban and Rieselfeld has provided a positive draw for families, with Rieselfeld's 'barrier-free' housing attracted a greater proportion of older residents, while a general lack of such housing across much of Vauban has been a deterrent for others. The combination of a strong, persistent and wellorganised grass roots movement in Freiburg, the availability of a large publicly-owned opportunity site after the withdrawal of the French military garrison in the early 1990's, and an enabling governance framework led by a strong executive mayor and a supportive municipal planning, has made Vauban rather a unique case. However, the emergence and growth of the group build model across Germany (Hamiduddin \& Gallent, 2013) and the effects of neighbourhood design on residential self-selectivity are aspects that may have greater relevance for planning policy makers generally. The research indicated that the building groups could act as an agent to residential self-selectivity by two important mechanisms. The first mechanism is financial and relates to the principal requirement for each household to raise sufficient private capital to cover the cost of the build in a way that excludes financially less able members of society (A, E). The second and related mechanism relates to stage of life and specifically the broader cultural tendency in Germany to enter private home ownership with the onset of family life (A, E). Together the two mechanisms orientate the group self-build approach towards more affluent younger families, as indicated in the demographic profile of residents and household sizes among residents of Vauban and Rieselfeld. 
Lastly, the literature indicates the existence of residential self-selectivity by residential design, and specifically through the provision of neighbourhood features including proximity and ease of access to particular transportation modes, amenities and employment, or through the qualities of housing or urban design, that are preferential to particular groups of prospective residents (Handy et al, 2006; Mokhtarian \& Cao, 2008). However, the potential exists for some design features to attract some but exclude others. For example, at Vauban and Rieselfeld the use of car-reduction measures to create traffic-free areas and priority for the social use of street space has created a child-friendly environment which provides an obvious draw for families. Together, the group build model and the car-reduced residential designs of Vauban and Rieselfeld provide an attractive housing implementation and housing design 'package' to families with young children. Yet few homes at Vauban are suitable to those with mobility restrictions and, with the majority of buildings built at four to five stories high but without elevator lifts, many are not well suited to the needs of elderly residents.

\section{[Table Six - about here]}

\subsection{Neighbourhood design strategies and social sustainability}

The three neighbourhoods compared in this section show concentrations of younger families in the new neighbourhoods, and particularly in Vauban - the most car-restrained neighbourhood - a pattern which echoes the 'cohort effect' previously experienced in Freiburg's new housing schemes. Although this may simply reflect the translation to consumption of demographically-driven demand, other factors may include the Baugruppen approach to building and the family-friendly, car-reduced residential design implemented at Vauban and Rieslefeld, which are themselves intimately linked with life stage and a wider cultural trend towards family home purchasing which contrasts with the 'housing ladder' approach pursued by householders in other countries including the UK (Hamiduddin \& Gallent, 2013). Car reduction strategies have had a pronounced effect on car ownership, although whether this is the direct product of residential self-selectivity was not investigated in detail. Similarly, a trend towards increasing neighbourly relations with car reduction has also been identified, although this is likely to be influenced by the community-strengthening use of the Baugruppen approach.

The empirical findings from Vauban and Rieselfeld suggest that both residential form and a socially oriented approach to housing development approach can encourage more intensive face-to-face contact between neighbours. As Mann (1958) noted, this does not mean that friendly relations will necessarily ensue, but it can be an important pre-condition. More problematically, in relation to 'sustainability of community' the demographic balance of the neighbourhoods does not reflect wider Freiburg society and is suggestive of a process of residential self-selectivity. Although there may be issues of access and social equity not investigated in this research, the low residential turnover experienced across the city suggests that stagnation and ageing in place may become a long term issue where the viability of services and amenities are undermined, and potential incomers are shut out.

\subsection{Freiburg's 'Fresh Cell' Strategy}

The existence of low residential turnover, ageing and neighbourhood decline in Freiburg's inter-war and post-war suburbs and the success of the city's new neighbourhoods in drawing younger residents that are attracted to the family-friendly, car-reduced residential design and Baugruppen housing approach has led to a recent policy rethink (A). Although Freiburg continues to experience high demand for new housing as its population continues to grow, 
the city has turned away from building large neighbourhood quarters and has recently focussed on creating small-scale 'fresh cell' developments to sustain demographically unbalanced or vulnerable neighbourhoods. The modest scale of the schemes allow for smaller opportunity sites to be developed. Such schemes are not intended to reverse population decline, but they serve as an interim measure to arrest decline prior to population regeneration. To the east of Freiburg's city centre, the district of Wiehre has two different examples of this approach at Wiehre Bahnhof and at the Katholische Siedlungswerk, representing Baugruppe-led and developer-led approaches, respectively (Table Seven).

On the site of Wiehre district's former station, this scheme used the Baugruppe approach exclusively to deliver 200 apartment homes that radiate in 'Wilhelminsian' vernacular style from a single shared surface home zone street (Fig.2), where car access is limited to settingdown and collection only. Car parking is provided in a subterranean garage beneath the site, accessed from an adjacent street and conforms to the overall city policy of 1.3 spaces per home. However, there the site is approximately $300 \mathrm{~m}$ away from a tram stop with high frequency connections into the city centre with a journey time of approximately 10 minutes. Significantly, this scheme applies the principles of car reduction and group self-build tested at both Vauban and Rieselfeld, and has emerged as a new model of car-reduced development to attract younger families into ageing neighbourhoods. The scheme has created a template which is being introduced into other ageing districts of the city including Landwasser-Mooswald, Haslach Egerten (adjacent to the Gardenstadt) and Weingarten (A).

\section{[Figure Two about here]}

Also in the district of Wiehre the Katholische Siedlungswerk presents an alternative design approach to the fresh cell model (Fig.3). Unlike the Baugruppen-led Wiehre Bahnhof, this scheme was built by a single not-for-profit developer selected from an open design competition, and contains 160 private apartment homes, a student residence, office space and a cafe. Approximately one third of the private homes are given to social housing, delivered as an obligation placed by the city authority as a condition for development. The site is traffic-free with the exception of a small area for parking adjacent to the office space, whilst car parking at a lower than average ratio of one space per home is provided in an underground car park. The scheme is located approximately $600 \mathrm{~m}$ directly north of Wiehre Bahnhof development on the opposite side of the Ganter Brauerei tram stop, which is $300 \mathrm{~m}$ away.

\section{[Figure 3 about here]}

In the absence of housing market 'churn' as regenerative force to maintain demographic balance within a neighbourhood, the fresh cell approach has emerged as a means to level population peaks and troughs and maintain population stability. In addressing the two key social sustainability concepts, the approach may have important social equity implications by ensuring that accessible neighbourhood amenities remain viable, and by producing a mechanism for residential replacement and therefore an important element for sustainability of community. For local economic and community planning there are important practical implications for maintaining demand for the amenities, services and infrastructure that cannot be redeployed or mothballed during periods of slack demand.

\section{Conclusions}

Even as a growing city with a burgeoning younger population, Freiburg has experienced issues of large-scale ageing as a result of single age cohorts settling together in the city's 
post-war suburbs. By applying the framework of social sustainability developed by Dempsey et al (2012) to these neighbourhoods, long term sustainability of community and social equity have emerged as issues. Although age structure is often overlooked as a determinant of social sustainability, Freiburg's experiences suggest that at a large scale and combined with low levels of housing market churn, the undermining of local services and amenities through long term depopulation challenges notions of community sustainability - through population replacement, and social equity - in accessibility terms.

Important markers have been laid down by the evolutionary experiences of Freiburg's postwar suburbs, both for the new neighbourhoods of Vauban and Rieselfeld whose narrow age structures echo their forebears, and for the consideration of social sustainability issues. In particular, the paper has raised tensions between population 'fixity' as an agent for strong community relations and 'churn' as a means to sustaining a population structure able to maintain local amenities. Closer examination of Vauban and Rieselfeld has identified two particular factors which may have influenced both population structure and social relations within each neighbourhood. The first is the group self-build housing model favours younger families able to access private finance and, as an inherently sociable approach to housing production, provides an important means for wider community bonding. The second is residential design which, by creating traffic-free streets where social functions are prioritised over automobiles, green spaces from potential car parking and encouraging propinquity, may also play an important if understated role in creating residential environments which appeal particularly to families and in enhancing social relations.

These outcomes create a number of policy conundrums. Firstly, whether to pursue residential design and housing production approaches which may create strong internal community bonds at the potential exclusion of other groups, secondly, at which scale new schemes that may be self-selective should be created and, thirdly, how issues of low housing market turnover should be managed in order to maintain necessary amenities and services. In Freiburg, these long term problem of large scale age concentration has influenced a change of tack away from larger new-build schemes towards smaller 'fresh cells' with the aim of attracting younger residents into ageing and depopulating neighbourhoods.

Although caution needs to be exercised in drawing and applying learning points from one context to another, this paper has emphasised the potentially important role of age structure in social sustainability and has provided a number of learning points for urban planners elsewhere. The first point is in having a basic understanding of how the spatial effect of demographic concentration can create longer term issues of social equity and sustainability of community in local communities. A second and related point is that such issues - that may become more prevalent in ageing societies where residents are better able to age in place - may be addressed by the injection of 'fresh cells' with family-friendly residential packages. Families are perhaps more likely to stay longer and integrate into a local community and contribute to stability than younger single occupant householders. Lastly, Freiburg's experience demonstrates how spatial demographic imbalances can be proactively managed by planners, with important implications for local economies and the viability of municipal infrastructure.

\section{Acknowledgements}

The author would like to thank the referees for their very helpful critique of an earlier draft of this paper. 


\section{References}

Academy of Urbanism \& City of Freiburg (2011) The Freiburg Charter for Sustainable Urbanism.

Appleyard, D. \& Lintell, M. (1971). The Environmental Quality of City Streets: The Residents Viewpoint. Journal of the American Institute of Planners, 38:84-101.

Appleyard, D., Gerson, S.M. \& Lintell, M. (1981) Livable Streets. Berkeley, UCLA Press.

Barlow, J., Jackson, R. and Meikle, J. (2001) Homes to DIY for: the UK's Self-build Housing Market in the Twenty-first Century, Joseph Rowntree Foundation, York.

Barnett, J. (1986) The Elusive City. New York, Harper \& Row.

Borgers, A., Snellen, D., Poleman, J. \& Timmermans, H. (2008). Preferences for Carrestrained Residential Areas. Journal of Urban Design 13 (2), 257-267.

Bramley, G., \& Power, S. (2009). Urban form and social sustainability: the role of density and housing type. Environment and planning. B, Planning \& design,36(1), 30.

Bramley, G., Dempsey, N., Power, S., Brown, C., \& Watkins, D. (2009). Social sustainability and urban form: evidence from five British cities. Environment and planning. A, 41(9), 2125.

Bramley, G., Dempsey, N., Power, S., \& Brown, C. (2006). What is 'social sustainability', and how do our existing urban forms perform in nurturing it? UK-Ireland Planning Research Conference. Bartlett School of Planning, University College, London.

Buchanan, C. (1963) Traffic in Towns. London, HMSO.

Buehler, R. \& Pucher, J. (2011) Sustainable Transport in Freiburg: Lessons from Germany's Environmental Capital. International Journal of Sustainable Transportation, 5 (1), 43-70.

Buehler, R., Jungjohann, A., Keeley, M., \& Mehling, M. (2011). How Germany Became Europe's Green Leader: A Look at Four Decades of Sustainable Policymaking'. Solutions.

Chance, T. (2009). Towards sustainable residential communities; the Beddington Zero Energy Development (BedZED) and beyond. Environment and Urbanization, 21(2), 527-544.

City of Freiburg (2010) Demographic Data. Unpublished Material. City of Freiburg.

City of Freiburg (2007) Demographischer Wandel in den Freiburger Stadtbezirken (Demographic Profiles in Freiburg's Districts). City of Freiburg.

Daseking, W. (2010) The Sustainable Suburbs of Vauban \& Rieselfeld. Unpublished Paper. City of Freiburg Department for Building Construction.

Davidson, M. (2010). Social sustainability and the city. Geography Compass,4(7), 872-880.

Dempsey, N. (2009). Are good-quality environments socially cohesive?: Measuring quality and cohesion in urban neighbourhoods. Town Planning Review, 80(3), 315-345.

Dempsey, N., Brown, C., \& Bramley, G. (2012). The key to sustainable urban development in UK cities? The influence of density on social sustainability. Progress in Planning, 77(3), 89-141.

Dempsey, N., Bramley, G., Power, S., \& Brown, C. (2011). The social dimension of sustainable development: defining urban social sustainability. Sustainable Development, 19(5), 289-300. 
Eastwood, M. (2008) Slateford Green Sustainable Transport Report. VIPRE Consultants, Edinburgh.

Evans, J., Jones, P. and Krueger, R. (2009). Organic regeneration and sustainability or can the credit crunch save our cities? Local Environment, 14, 683-698.

Forrest, R. \& Kearns, A. (2001) Social Cohesion, Social Capital and the Neighbourhood. Urban Studies, 38 (12) 2125-2143.

Hamiduddin, I. (2014) The Car in the Neighbourhood: Residential Design and Social Outcomes in Southern Germany. In: Hickman, R., Givoni, M., Bonilla, D., Banister, D. (2014) An International Handbook on Transport and Development. Edward Elgar: Cheltenham.

Hamiduddin, I. \& Daseking, W (2014). Community-Based Planning in Freiburg, Germany: The Case of Vauban. In: Gallent, N. and Ciaffi, D. Community Action and Planning. Policy Press, Bristol.

Hamiduddin, I. \& Gallent, N. (2013) 'Custom Build' Neighbourhoods: Examining the 'Double Win'of Housing Production and Community Development Through Group-Build'. Unpublished (available from the author).

Handy, S., Cao, X. \& Mokhtarian, P.L. (2006) Self-Selection in the Relationship Between the Built Environment and Walking: Empirical Evidence From Northern California. Journal of the American Planning Association, 72 (1), 55-74.

Hart, J. and Parkhurst, G. (2011) Driven to excess: Impacts of motor vehicles on the quality of life of residents of three streets in BristolUK. World Transport Policy \& Practice, 17 (2), 12 30 .

Harvey, D. (2000) MegaCities: Lecture 4. Amersfoort, Tynstra Gudde Management Consultants.

Hass-Klau, C. (1990) The Pedestrian and City traffic. London, Belhaven press.

Hillier, J. (2007). Stretching beyond the horizon: a multiplanar theory of spatial planning and governance. Aldershot, Ashgate.

Hillman, M., Adams, J. \& Whitelegg, J. (1990). One False move: A study of children's independent mobility. London, PSI.

Kaplan, S. (1995) The Restorative Benefits of Nature: Toward an Integrative Framework. Journal of Environmental Psychology, 15, 169-183.

Kay, A. (2005). Territorial justice and devolution. British Journal of Politics and International Relations, 7, 544-560.

Kuo, F.E. \& Sullivan, W.C. (2001) Environment and Crime in the Inner City: Does Vegetation Reduce Crime? Environment \& Behaviour, 33, 343-367.

Maller, C., Townsend, M., Prior, A., Brown, P. \& St Leger, L. (2005) Healthy Nature Healthy People: 'Contact with Nature' as an Upstream Health Promotion Intervention for Populations. Health Promotion International, 21 (1), 45-54.

Mann, P. H. (1958). The socially balanced neighbourhood unit. Town planning review, 29(2), 91-97. 
Melia, S. (2010) Urban intensification and problems - real and imagined. Town and CountryPlanning.

Mokhtarian, P.L. \& Cao, X. (2008) Examining the Impacts of Residential Self-Selection on Travel Behaviour: A Focus on Methodologies. Transportation Research Part B: Methodologies, 42 (3), 204 -228.

Muller, B., \& Siedentop, S. (2004). Wachstum und Schrumpfung in Deutschland-Trends, Perspektiven und Herausforderungen fur die raumliche Planung und Entwicklung. [Growth and shrinkage in Germany Trends, prospects and challenges for spatial planning and development] Deutsche Zeitschrift für Kommunalwissenschaften,43(1), 14-32.

Nobis, C. \& Welsch (2003) Mobility management at district level - The impact of car-reduced districts on mobility behavior. Proceedings of the 7. European Conference on Mobility management ECOMM.

Perry, C. (1939) Housing for the Machine Age. New York, Russell Sage Foundation.

Putnam, R. (2000) Bowling Alone: The Collapse and Revival of American Community. Simon and Schuster, New York.

Polèse, M., \& Stren, R. E. (2000). The social sustainability of cities: Diversity and the management of change. In: Polèse, M., \& Stren, R. E. (Eds). The social sustainability of cities: Diversity and the management of change. University of Toronto Press, Toronto.

Portes, A. (2000). Social capital: Its origins and applications in modern sociology. LESSER, Eric L. Knowledge and Social Capital. Boston: Butterworth-Heinemann, 43-67.

Raco, M. (2007) Building Sustainable Communities: Spatial Policy and Labour Mobility in Post-War Britain. The Policy Press, Bristol.

Ryan, S. \& Throgmorton, J.A. (2003) Sustainable Transportation and Land Development on the Periphery: The Case of Freiburg, Germany and Chula Vista, California. Transportation Research Part D, 8, 37-52.

Rydin, Y. (2010). Governing for sustainable urban development. Abingdon, Earthscan

Sarkissian, W. (1976). The idea of social mix in town planning: an historical review. Urban Studies, 13(3), 231-246.

Scheurer, J. (2001) Car-Free Housing in European Cities. Murdoch University. (http://wwwistp.Murdoch.edu.au/publications/projects/carfree/carfree.html)

Siedentop, S., \& Fina, S. (2010). Urban Sprawl beyond Growth: the Effect of Demographic Change on Infrastructure Costs. Flux, (1), 90-100.

Smith, H. A., \& Furuseth, O. J. (2004). Housing, Hispanics, and Transitioning Geographies in Charlotte, North Carolina. southeastern geographer, 44(2), 216-235.

Southworth, M. \& Ben-Joseph, E. (2002) Streets and the shaping of towns and cities. McGraw-Hill, New York.

Stein, C. (1950) Towards New Towns for America. Liverpool, University of Liverpool Press.

Stren, R. and Polese, M. (2000). Understanding the new sociocultural dynamics of cities: comparative urban policy in a global context. In: Polese, M. and Stren, R. (Eds) The social sustainability of cities: diversity and the management of change. University of Toronto Press, Toronto. 
Strife, D. \& Downey, L. (2009) Childhood Development and Access to Nature, A New Direction for Child Inequality Research. Organisation Environment, 22(1) 99-122.

Susilo, Y.O., Williams, K., Lindsay, M. and Dair, C. (2012) The influence of individuals' environmental attitudes and urban design features on their travel patterns in sustainable neighbourhoods in the UK. Transportation Research Part D: Transport and Environment, 17 (3), 190-200.

Vallance, S., Perkins, H. C., \& Dixon, J. E. (2011). What is social sustainability? A clarification of concepts. Geoforum, 42(3), 342-348.

Žižek, S. (1989). The sublime object of ideology. New York, Verso Books 